\title{
Correlation of Ambient Air Quality with the Sudden Reduction in Mining Activity in a Complex of Lignite Mines ${ }^{\dagger}$
}

\author{
Chariton Sachanidis, Francis Pavloudakis * and Christos Roumpos (1)
}

check for

updates

Citation: Sachanidis, C.; Pavloudakis,

F.; Roumpos, C. Correlation of

Ambient Air Quality with the

Sudden Reduction in Mining Activity in a Complex of Lignite Mines. Mater. Proc. 2021, 5, 102. https://doi.org/ $10.3390 /$ materproc2021005102

Academic Editor: Evangelos Tzamos

Published: 17 January 2022

Publisher's Note: MDPI stays neutral with regard to jurisdictional claims in published maps and institutional affiliations.

Copyright: (C) 2022 by the authors. Licensee MDPI, Basel, Switzerland. This article is an open access article distributed under the terms and conditions of the Creative Commons Attribution (CC BY) license (https:// creativecommons.org/licenses/by/ $4.0 /)$.
Mining Engineering Department, Public Power Corporation, 10432 Athens, Greece; ca.sachanidis@dei.gr (C.S.); c.roumpos@dei.gr (C.R.)

* Correspondence: fpavloudakis@uowm.gr

+ Presented at International Conference on Raw Materials and Circular Economy, Athens, Greece, 5-9 September 2021

\begin{abstract}
Under the pressure of competition, primarily caused by the high price of carbon dioxide emission allowances, lignite production in Western Macedonia Lignite Centre dramatically reduced in the last decade. This development affects the ambient air quality of the greater lignite mine area, as evidenced by the reducing particulate matter concentrations and the number of exceedances of daily average concentrations per year. Moreover, differences in air quality measurements of monitoring stations, with regard to their distance from mining activities, now tend to be minimized. Based on these facts, it can be predicted that, after the phase-out of electricity generation activities, the ambient air quality will reach the levels that are typical for rural areas of Northern Greece well before the end of the mines' land reclamation programs.
\end{abstract}

Keywords: lignite; surface mining; particulates emissions; ambient air quality

\section{Introduction}

The elimination of the coal and lignite share in the energy mix is a priority of EU energy policy. In this context, many European power utilities have already started to implement programs to gradually reduce the use of coal and lignite, turning either to natural gas as a transitional fuel or directly to renewable energy sources [1].

The exploitation of lignite deposits in the Ptolemaida basin (region of Western Macedonia) dominated the electricity sector of Greece for more than six decades, boosting economic growth and energy security [2-4]. Until recently, plans were provided for the operation of mines and steam power stations until 2042 [3]. However, under the pressure of competition mainly caused by the high price of carbon dioxide emission allowances, lignite transformed from a blessing to an environmental, social, political and economic problem [4]. In this frame, lignite production dramatically reduced in recent years, while the definitive closure of mining activity was rescheduled for 2028 [1]. However, there are still doubts about how this evolution will be environmentally friendly [4], socially just and effective across multiple sustainability dimensions [2].

In addition to the clear negative impacts, this development positively affects the ambient air quality of the greater lignite mines area, as evidenced by the data of a dense network of monitoring stations, which makes the basin of Ptolemaida the best monitored area throughout Greece. Based on these records, many researchers thoroughly investigated the relation of particulates emissions and ambient air quality in relation to the surface mining and electricity generation activities carried out in Ptolemaida basin. A spatial-temporal analysis of the particle size distribution of fly ash and fugitive dust in combination with the Total Suspended Particles and PM10 concentrations recorded in 13 monitoring stations for a seven-year-period, indicated that the complex terrain, the different characteristics of the pollution sources and the variable meteorological conditions considerably affect 
the pollution due to emissions of particulates [5]. Moreover, a fractal analysis of measurements carried out in the commercial center of the city of Kozani, the capital of the Western Macedonia region, showing that the mean PM10 and PM2.5 concentrations exceeded the specified limits, while the average PM2.5/PM10 ratio was 0.42 , which was indicative of the large portion of coarser particles in PM content. The study also concluded that the sources responsible for background measurements were not the same as those responsible for high pollution episodes [6]. Another study, which investigated the contribution of fly ash emissions of lignite-fired power stations to the air pollution of the Western Macedonia region, determined that fly ash particles, such as cenospheres, vesicular spheres, spheroids, dense spheres and chars were found in almost every filter collected in the area, with those located close to power plants appearing to have fly ash particles that were coarser and greater in number [7].

To quantify particulates emissions, dispersion simulation models are usually used, incorporating emission factors that characterize various pollution sources. Bibliographical sources detail the limited availability of such factors, which are not representative for all mining operations [8]. Therefore, in the case of the lignite surface mines of the Ptolemaida basin, a three-year campaign of field measurements was carried out to collect the necessary meteorological data and upwind-downwind concentration levels in the vicinity of the main particulates' emission sources derived from the surface mines [9]. By applying an inverse dispersion approach using two different models, emissions factors were calculated, and empirical formulas were developed for the total fugitive dust emission estimations, in accordance with the EU Regulation 166/2006, which imposes mining enterprises to quantify their pollutants emissions from their fugitive sources [9-11].

Another PM10 measurement campaign was conducted over one year at the three receptor sites. The highest PM10 concentration values were recorded in the city of Ptolemaida, where the mean annual concentration was equal to the limit value of $40 \mu \mathrm{g} / \mathrm{m}^{3}$, while $23 \%$ of PM10 concentrations exceeded the daily EU limit value (see next paragraph). The source apportionment results of a positive matrix factorization (PMF) receptor model identified that, in Kozani, the main particulates sources were coal combustion and roadtraffic emissions; in Ptolemaida, they were coal combustion, road-traffic emissions and dust transferred from surface mines; and in Eratyra (rural area far away from the lignite mines), they were soil dust and biomass-wood burning [12]. Furthermore, the contribution of fugitive dust emissions from the lignite mines to the ambient levels of PM10 in the surroundings was also estimated by performing chemical mass balance (CMB) receptor modeling. Sources with significant contribution were vehicular traffic, biomass burning, and secondary sulfate and nitrate aerosol. In contrast, the estimated total contribution of mines ranged between 9 and $22 \%$ in the cold period, increasing to $36-42 \%$ in the dry, warm period [13], despite the preventive, containment and suppression measures that were applied for controlling all emissions sources [14].

\section{Methods}

The ambient air quality measurements used in the frame of the present study were collected by a network of eleven monitoring stations that are dispersed in the entire basin of Ptolemaida. The stations were installed by the Greek Public Power Corporation. The recorded measurements are accessed online by the Region of Western Macedonia, which acts as the supervisory authority.

For the purposes of this study, PM10 and PM2.5 concentrations were processed and evaluated based on the following criteria: (i) the daily average limit value of PM10 is $50 \mu \mathrm{g} / \mathrm{m}^{3}$ and must not be exceeded more than 35 times per calendar year; (ii) the annual average limit value of PM10 is $40 \mu \mathrm{g} / \mathrm{m}^{3}$; and (iii) the annual average limit value of PM2.5 is $25 \mu \mathrm{g} / \mathrm{m}^{3}$. These criteria are determined by the European Commission Directive 2008/50/EC.

Furthermore, ambient air quality measurements were correlated with data related to the total excavations and lignite production of the lignite mines, which were obtained from 
the annual and monthly operational reports of the Western Macedonia Lignite Centre of Public Power Corporation SA.

\section{Results}

The fluctuations of the total annual excavations of four surface lignite mines of the Ptolemaida basin, and the main ambient air quality parameters of five monitoring stations that were located in the greater mining area, are presented in Figure 1. Ambient air quality is expressed as annual, average PM10 and PM2.5 concentrations and the number of exceedances per annum of the daily average PM10 concentration limit of $50 \mu \mathrm{g} / \mathrm{m}^{3}$. The reduction in excavated rock volumes and, consequently, the reduction in lignite quantities burnt in the thermal power plants located at the mine mouth resulted in a considerable improvement in ambient air quality and the minimization of air pollution incidences. However, this development exhibits different characteristics between the four examined surface mines. For instance, the reduction in pollution incidences recorded in Proastio monitoring station (Figure 1a) was gradual, while that of Kilada station (Figure 1c) exhib large fluctuations that did not follow the annual fluctuations of the total excavated volumes of the South Field mine.

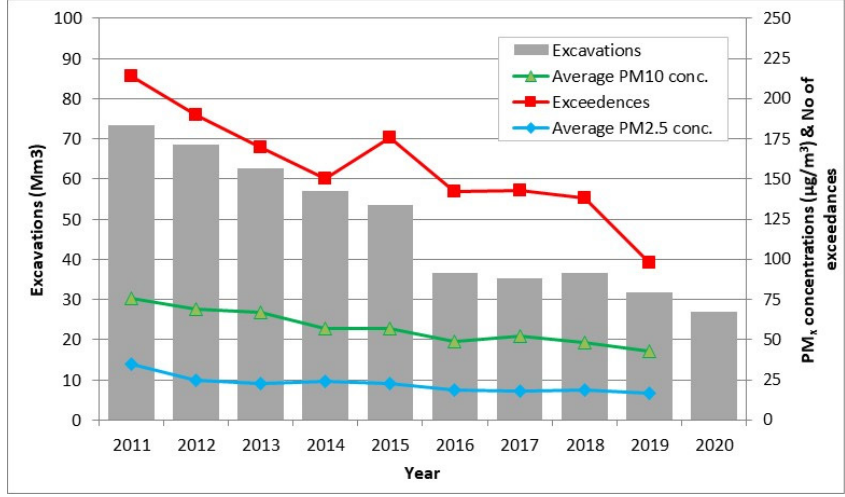

(a)

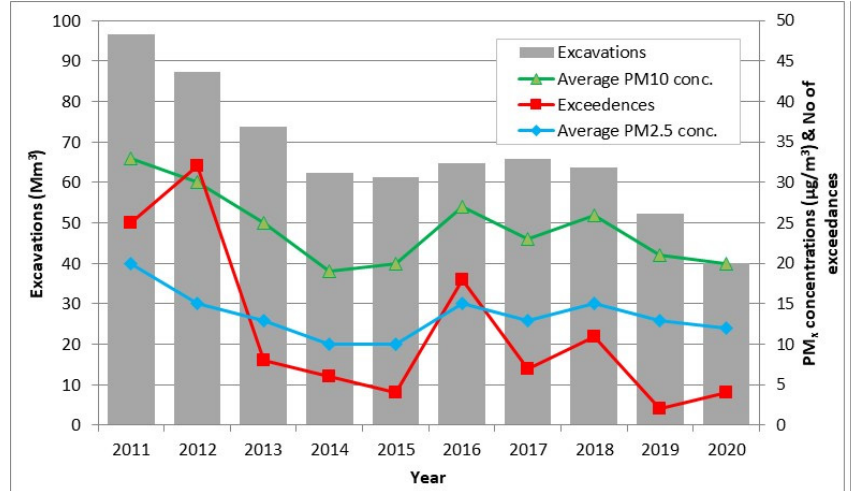

(c)

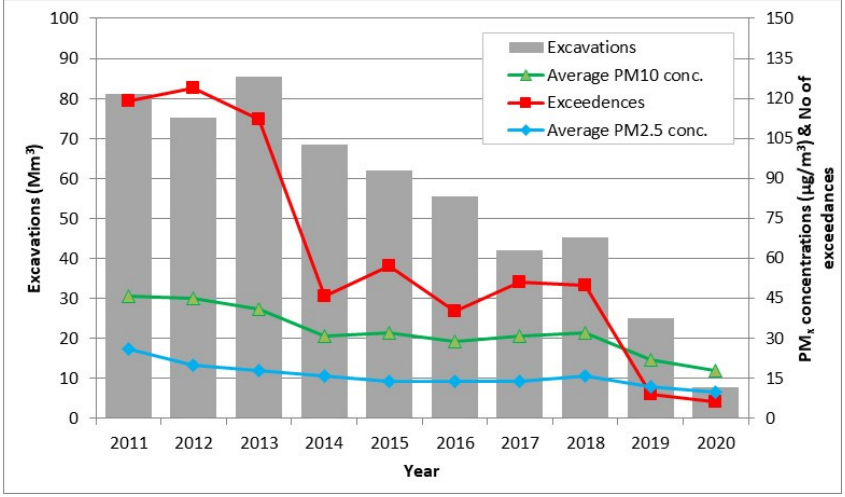

(b)

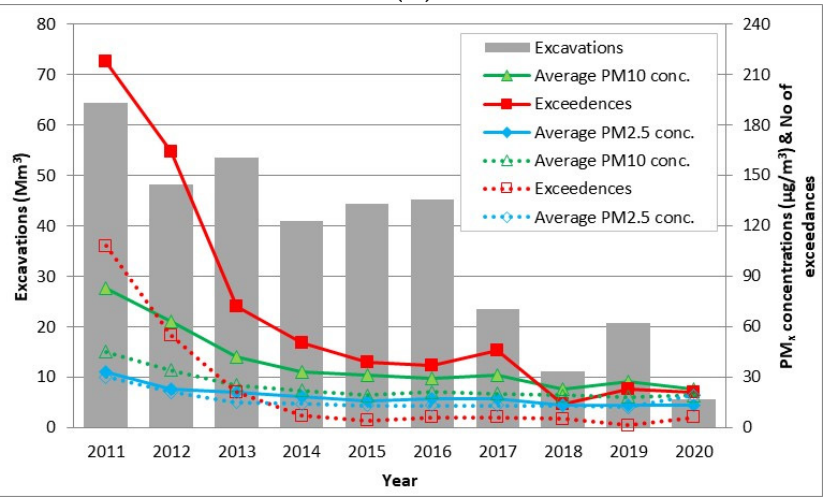

(d)

Figure 1. Annual variations of total rock excavations in four different lignite mining fields of the Ptolemaida basin, average PM10 and PM2.5 concentrations and number of exceedances of the daily average PM10 concentrations from the limit value of $50 \mu \mathrm{g} / \mathrm{m}^{3}$ as recorded in monitoring stations (MS) located in the vicinity of the mines: (a) Main Field vs. Proastio MS; (b) Kardia Field vs. Pontokomi MS; (c) South Field vs. Kilada MS; (d) Amynteo mine vs. Anargiri MS (solid line) and Amynteo MS (dashed line).

In Figure 2, the correlation of the total annual excavations in each of the four surface mines under investigation is presented, along with the ambient air quality, which is expressed as annual, average PM10 and PM2.5 concentrations and the number of exceedances per annum of the daily PM10 concentration limit of $50 \mu \mathrm{g} / \mathrm{m}^{3}$. The correlation is considered 
strong for all four mines. The Mavropigi mine (Figure 2a) exhibits the highest R-squared value for linear regression for all the three examined ambient air quality parameters. The Kardia Field, South Field and Amynteo mines (Figure 2b-d) also demonstrate high Rsquared values, which are even higher in case of the number of exceedances of the specified PM10 concentration limit for exponential regression.

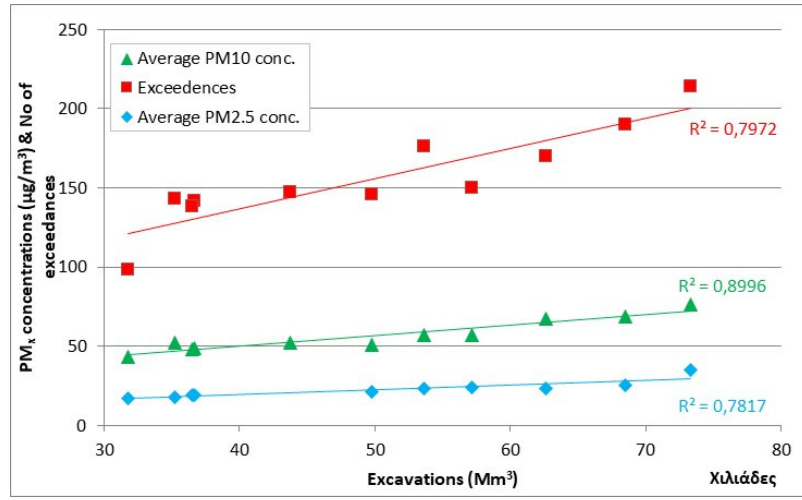

(a)

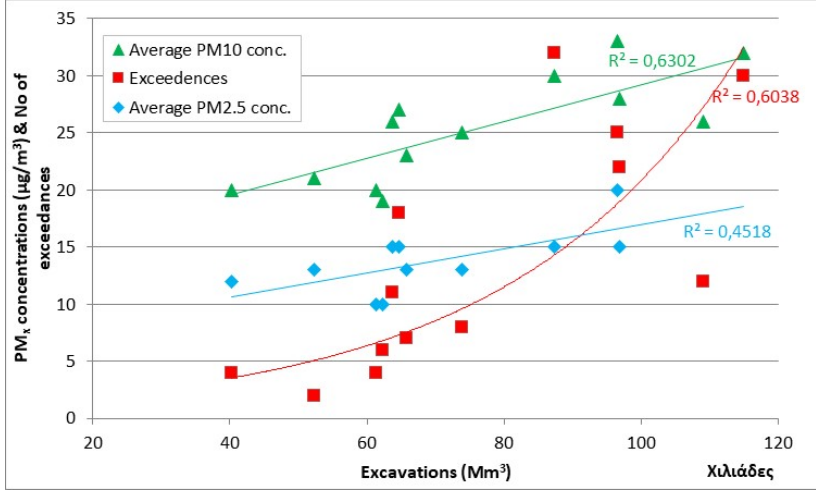

(c)

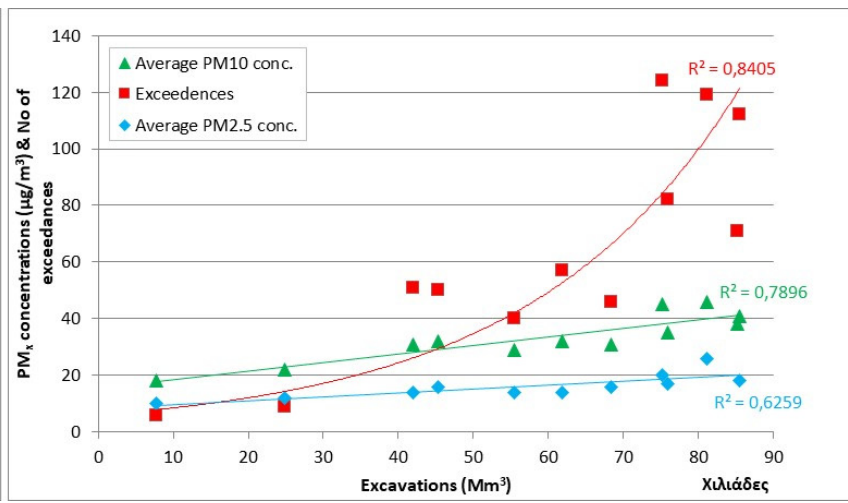

(b)

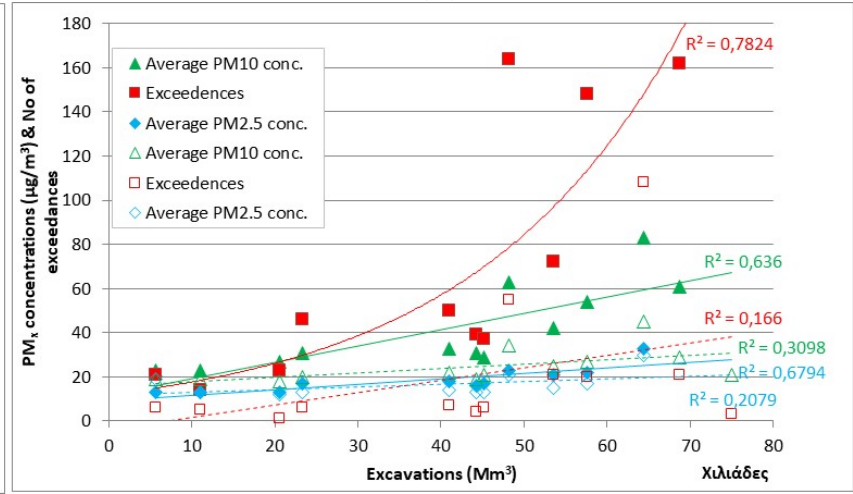

(d)

Figure 2. Correlation of the average PM10 and PM2.5 concentrations and number of exceedances of the daily average PM10 concentrations from the limit value of $50 \mu \mathrm{g} / \mathrm{m}^{3}$, as recorded in monitoring stations (MS) located in the vicinity of the mines, with the total annual rock excavations in four different lignite mining fields of Ptolemaida basin: (a) Main Field vs. Proastio MS; (b) Kardia Field vs. Pontokomi MS; (c) South Field vs. Kilada MS; (d) Amynteo mine vs. Anargiri MS (solid line) and Amynteo MS (dashed line).

Moreover, in the case of Amynteo mine, the records of two different monitoring stations are correlated with the variation of excavated rock volumes. Anargiri station is located in a village close to the mining activities, while Amynteo station is located in a small town $5 \mathrm{~km}$ north of the mine. As expected, the air quality measurements in the monitoring station located further from the mining activities exhibit a minimum correlation with the fluctuations of the rock excavations.

\section{Discussion}

The reduction in the total annual excavations in the Ptolemaida basin mines resulted in a considerable reduction in air pollution problems. The reduction in the number of exceedances of the daily average PM10 concentration limit of $50 \mu \mathrm{g} / \mathrm{m}^{3}$ per year, which were recorded in five monitoring stations, varied between $78-99 \%$, while for the annual average PM10 and PM2.5 concentrations, the reduction varied between $42-72 \%$ and $50-62 \%$, respectively. The fact that this improvement is measured higher in terms of the number of exceedances, rather than the average concentrations, confirms the conclusions of a previous study [6] on the different pollution sources that are responsible for background and pick 
concentrations, implying that most of the air pollution episodes are related to the lignite exploitation and the seasonal phenomenon of dust transfer from the Sahara desert.

The Amynteo monitoring station is located far from the mining activities in a direction that does not favor the transport of particulates from the winds prevailing in this part of Ptolemaida basin, and was used as reference station for a preliminary comparative analysis. Accordingly, the gradual reduction in rock excavations in all four surface mines under investigation corresponds to a tendency to minimize the differences between the ambient air quality parameters measured in monitoring stations, which were located close to the mines and thermal power plants (Proastio, Pontokomi, Kilada and Anargiri); these parameters were measured in stations located relatively further away (Amynteo station). Based on this fact, it can be safely predicted that the phase-out of lignite mining activities will result in air pollution close to the background level for rural areas of Southern Europe, which is determined mainly from seasonal agricultural activities and operation heating systems during the winter. In addition, this development will happen regardless of the progress of the land reclamation/repurposing program that is applied.

Furthermore, an effort was made to improve the correlation of ambient air quality measurements of the Kilada monitoring station with the rock excavations of South Field mine using meteorological data from the National Observatory of Athens monitoring station, which was installed in the South Field mine. By taking into account the annual precipitation values, the R-squared values for the correlation of mine excavations with PM10 and PM2.5 concentrations and number of exceedances were increased from 0.6302, 0.4518 and 0.5662 to $0.7950,0.5729$ and 0.6769 , respectively. Therefore, a stepwise regression analysis is considered appropriate if the optimization of an algorithm for predicting ambient air quality is required.

On the contrary, the use of dust emissions volumes, calculated based on the emissions factors determined in previous studies [11] instead of the annual excavated rock volumes, did not improve the already positive correlation with the examined ambient air quality parameters.

\section{Conclusions}

The reduction in the excavated rock volumes and the lignite quantities produced in the surface mines of Western Macedonia Lignite Centre during the last decade resulted in a significant improvement in ambient air quality in the greater lignite-bearing basin. This was found particularly in areas where mining activities had ceased operations, such as the Amynteon and Kardia mines.

Based on the analysis presented in the previous paragraphs, it can be predicted that, after the phase-out of electricity generation activities, the ambient air quality will reach the levels that are typical for rural areas of Northern Greece. The contribution of diffuse sources, such as the thousands of acres of excavation sites and, predominantly, dumps of wasted rocks and ash that are covered by limited vegetation, seem to be insufficient for causing a large number of pollution episodes. This is an important conclusion considering that the closure of lignite mines has recently been rescheduled from 2042 to 2028 (with the closure year likely to be revised from 2028 to another date depending on the future electricity market). Moreover, the current ratio of active/already reclaimed mining areas makes impossible the development and implementation of an effective land repurposing program at that time.

Author Contributions: Conceptualization, F.P.; methodology, C.S., F.P. and C.R.; software, C.S.; validation, C.S., F.P. and C.R.; formal analysis, C.S., F.P. and C.R.; investigation, C.S., F.P. and C.R.; resources, C.S. and F.P.; data curation, C.S., F.P. and C.R.; writing—original draft preparation, F.P.; writing - review and editing, C.S., F.P. and C.R.; visualization, C.S., F.P. and C.R. All authors have read and agreed to the published version of the manuscript.

Funding: This research received no external funding.

Institutional Review Board Statement: Not applicable. 
Informed Consent Statement: Not available.

Data Availability Statement: The data supporting reported results is submitted on an annual basis to the Greek Ministry of Environment and Energy, the Mines' Inspectorate of Northern Greece and the Region of Western Macedonia.

Conflicts of Interest: The authors declare no conflict of interest.

\section{References}

1. Pavloudakis, F.; Roumpos, C.; Karlopoulos, E.; Koukouzas, N. Sustainable rehabilitation of surface coal mining areas: The case of Greek lignite mines. Energies 2020, 13, 3995. [CrossRef]

2. Nikas, A.; Neofytou, H.; Karamaneas, A.; Koasidis, K.; Psarras, J. Sustainable and socially just transition to a post-lignite era in Greece: A multi-level perspective. Energy Sources Part B Econ. Plan. Policy 2020, 15, 513-544. [CrossRef]

3. Roumpos, C.; Pavloudakis, F.; Liakoura, A.; Nalmpanti, D.; Arampatzis, K. Utilisation of Lignite Resources within the Context of a Changing Electricity Generation Mix. In Proceedings of the 10th Jubilee Intl. Brown Coal Mining Congress: "Brown Coal Today and in the Future", Bełchatów, Poland, 16-18 April 2018.

4. Vlassopoulos, C. Persistent lignite dependency: The Greek energy sector under pressure. Energy Policy 2020, $147,111825$. [CrossRef]

5. Triantafyllou, A.G.; Zoras, S.; Evagelopoulos, V. Particulate matter over a seven year period in urban and rural areas within, proximal and far from mining and power station operations in Greece. Environ. Monit. Assess. 2006, 122, 41-60. [CrossRef] [PubMed]

6. Evagelopoulos, V.; Zoras, S.; Triantafyllou, A.G.; Albanis, T.A. PM10-PM2.5 time series and fractal analysis. Glob. NEST J. 2006, 8 , 234-240.

7. Iordanidis, A.; Buckman, J.O.; Triantafyllou, A.G.; Asvesta, A. Fly ash-airborne particles from Ptolemaida-Kozani area, northern Greece, as determined by ESEM-EDX. Int. J. Coal Geol. 2008, 73, 63-73. [CrossRef]

8. Triantafyllou, A.G.; Moussiopoulos, N.; Garas, S.; Krestou, A.; Douros, I.; Diamantopoulos, C.; Skordas, J.; Matthaios, V.; Leivaditou, H.; Tsegas, G.; et al. Theofrastos: PMx emission factors-Dispersion from fugitive dust sources in lignite mines of Western Macedonia, Greece. In Proceedings of the 14th International Conference on Environmental Science and Technology, Rhodes, Greece, 3-5 September 2015.

9. European Council. Regulation (EC) No. 166/2006 of the European Parliament and of the Council of 18 January 2006 Concerning the Establishment of a European Pollutant Release and Transfer Register and amending Council Directives 91/689/EEC and 96/61/EC. Off. J. Eur. Union 2006, 49, 33.

10. US EPA. AP42, Compilation of Air Pollutant Emission Factors, Volume 1: Stationary Point and Area Sources; Chapter 11.9 Western Surface Coal Mining, 5th ed.; US EPA: Research Triangle Park, NC, USA, 1998.

11. Triantafyllou, A.G.; Moussiopoulos, N.; Krestou, A.; Tsegas, G.; Barmpas, F.; Garas, S.; Andreadou, S. Application of inverse dispersion modelling for the determination of PM emission factors from fugitive dust sources in open-pit lignite mines. Int. J. Environ. Pollut. 2018, 62, 274-290. [CrossRef]

12. Garas, S.K.; Triantafyllou, A.G.; Zapsis, S.; Diamantopoulos, C.; Skordas, J.; Bartzis, J.G. PM10 concentrations, trace elements and sources' identification in three representative receptors of Western Macedonia, Greece. In Proceedings of the 15th Conference on Environmental Science and Technology, Rhodes, Greece, 31 August-2 September 2017.

13. Samara, C.; Argyropoulos, G.; Grigoratos, T.; Kouras, A.; Manoli, E.; Andreadou, S.; Pavloudakis, F.; Sachanidis, C.G. Chemical characterization and receptor modeling of PM10 in the surroundings of the opencast lignite mines of Western Macedonia, Greece. Environ. Sci. Pollut. Res. 2018, 25, 12206-12221. [CrossRef] [PubMed]

14. Filiou, K.F.; Sachanidis, H.G.; Pavloudakis, F. Control of fugitive material in surface lignite mines. In Proceedings of the 16th International Symposium on Environment Pollution and its Impact on Life in the Mediterranean Region, Ioannina, Greece, 24-27 September 2011. 